\title{
FAKTOR-FAKTOR YANG MEMPENGARUHI LITERASI KESEHATAN MASYARAKAT DI PUSKESMAS BANGUNTAPAN I BANTUL D.I.Y
}

\author{
Tutik Wahyuningsih \\ Stikes Surya Global Yogyakarta \\ Email: tutikwahyuaningsih86@gmail.com
}

\begin{abstract}
ABSTRAK
Latar Belakang: Hasil dari study pendahuluan yang dilakukan dapat dapat diketahui bahwa tingkat literasi kesehatan masyarakat di Puskesmas Banguntapan I masih tergolong rendah hal ini diketahui ketika peneliti melakukan uji coba terhadap 10 responden dengan menggunakan NVS (New Vital Sign) dari 6 pertanyaan mengenai sebuah label nutrisi es krim 7 dari 10 responden tersebut memiliki tingkat literasi rendah yaitu dengan skor 1-2 tergolong kategori rendah, peneliti menggunakan label nutrisi es krim karena untuk mengetahui tingkat literasi kesehatan masyarakat yang berobat di Pukesmas Banguntapan I Tujuan: Untuk mengetahui faktor usia, pendidikan dan pekerjaan yang berpengaruh terhadap literasi kesehatan di Puskesmas Banguntapan I. Metode Penelitian: Jenis penelitian ini Deskriptif kuantitatif dengan rancangan cross sectional. Instrumen penelitian ini menggunakan kuesioner NVS (Newest Vital Sign). Variabel yang diukur yaitu usia, pendidikan, pekerjaan yang dihubungkan dengan literasi kesehatan. Data primer dianalisis dengan menggunakan uji chi square. Sampel dalam penelitian ini berjumlah 100 responden pasien di Puskesmas Banguntapan I. Hasil Penelitian: Ada pengaruh Usia terhadap literasi kesehatan $(\mathrm{p}=0,038 \%<0,05)$, Ada pengaruh pendidikan terhadap tingkat literasi kesehatan $(\mathrm{p}=0,000<0,05)$, ada pengaruh pekerjaan terhadap tingkat literasi kesehatan $(\mathrm{p}=0,043<0,05)$. Kesimpulan: Berdasarkan hasil analisis data ada pengaruh antara usia, pendidikan, dan pekerjaan terhadap literasi kesehatan.
\end{abstract}

Kata kunci: Health Literacy, Pekerjaan, Pendidikan, Usia

\begin{abstract}
Background: The results of the preliminary study conducted can be seen that the level of public health literacy at puskesmas banguntapan I still relatively low this is known when researchers conducted a trial of 10 respondents by using NVS (New Vital Sign) of the 6 questions about an ice cream nutrition label 7 of the 10 respondents had a low literacy level with a score of 1-2 classified as a low category, researchers used the ice cream nutrition label because to determine the lavel of public health literacy the treatment at puskesmas banguntapan I. Objective: to find out the factor age, education, work that influence health at literacy at Puskesmas Banguntapan I. Methods: This type of research uses quantitative descriptive with cross sectional design. The instrument of this study used the NVS questionnaire (Newest Vital Sign). The variables measured are age, education, work that is associated with health literacy. Primary data were analyzed using the chi square test. The sample in this study amounted to 100 respondents in the Puskesmas Banguntapan I. Result : there is influence of age on health literacy $(p=0,038 \%<0,05)$. There is an influence of education on health literacy $(p=0,000<0,05)$, there is effect of work on the level of health literacy $(p=0,043<0,05)$. Conclusion: Based on the results of data analysis there is an influence between age, education, and work on health literacy.
\end{abstract}

Keywords: Health Literacy, work, education, age 


\section{PENDAHULUAN}

Health literacy atau kemelekan merupakan kemampuan yang penting untuk dimiliki seseorang karena dengan memiliki kemampuan literasi paling dasar pun seseorang dapat lebih meningkatkan pengetahuan dan potensi untuk mencapai tujuan mereka sehingga dapat berpartisipasi lebih di masyarakat, baik secara ekonomi maupun sosial (Public Health in the 21st Century: Health Literacy in Context: International Perspectives, 2012).

Di Indonesia, penelitian literasi kesehatan masih sangat terbatas, namun sebagai data di luar negeri ditemukan hubungan yang konsisten antara literasi kesehatan rendah (diukur dengan kemampuan membaca) dan pengetahuan yang berhubungan dengan kesehatan yang lebih terbatas dan pemahamannya serta literasi kesehatan memiliki hubungannya dengan variabel sosiodemografi, persepsi diri, kesehatan, dan kondisi kronis pada pasien pelayanan kesehatan primer (Berkman, Sheridan SL, Donahue KE, Halpern DJ, Crotty K. Low., 2011; Jovic-vranes, Bjegovic-Mikanovic, V., Marinkovic 2011).

Literasi kesehatan umumnya dikaitkan dengan kemampuan membaca dan menulis seseorang. Hal ini sesuai dengan definisi literasi kesehatan yang dinyatakan oleh The American Medical Association yang mewakili model biomedis sebagai kemampuan membaca dan memahami resep obat, kartu berobat dan bentuk materi lainnya yang berhubungan dengan peran dirinya sebagai pasien.(Purwanti Hadisiwi, Jenny Ratna Suminar, 2016).

Numerik atau berhitung berkaitan dengan kemampuan memahami informasi gizi yang ada dalam kemasan produk pangan atau obat, berkaitan pula dengan kemampuan memahami dosis obat yang harus diminum untuk pengobatan, dan berkaitan pula dengan pemilihan asuransi atau jaminan kesehatan. Penyelenggara kesehatan yang lebih berpengalaman dalam berkomunikasi dengan pasien seharusnya dapat membantu pasien untuk dapat memahami informasi yang berkaitan dengan numerik ini. (Purwanti Hadisiwi , Jenny Ratna Suminar.2016)

Sampai saat ini literasi kesehatan masih menjadi masalah baik di Negara maju maupun berkembang. Di amerika serikat, kurang lebih setengah orang dewasa memiliki tingkat literasi kesehatan yang kurang (Safeer \& Keennan, 2005). Survei yang dilakukan di kanada pada tahun 2013 memberikan hasil sekitar 60\% penduduk dewasa disana tidak memiliki tingkat literasi kesehatan yang cukup (Canadian Council on Learning,2008). Penelitian di Belgrade, Serbia menunjukkan hasil $41 \%$ responden memiliki tingkat literasi kesehatan yang kurang, sedangkan hasil sebuah survei nasional di Taiwan pada tahun 2003 menyatakan 30,3\% penduduk tidak memiliki tingkat literasi kesehatan yang cukup ( Lee, Tsai, Tsai dan kuo,2010 ). Studi serupa di Turki memberikan hasil $71,9 \%$ responden memiliki tingkat literasi kesehatan yang rendah (Odzemir, Alper, Z., Uncu, Y., \& Bilgel,2010).

NVS merupakan alat skrining atau penapisan untuk pasien dengan tingkat literasi kesehatan yang rendah dan hanya membutuhkan waktu 3 menit untuk melakukannnya. Tes tingkat literasi kesehatan menggunakan NVS dilakukan dengan memberikan responden sebuah label nutrisi es krim. Setelah itu responden diminta untuk menjawab enam pertanyaan yang jawabannnya diambil dari informasi yang tertera pada label nutrisi es krim tersebut. Pertanyaan dalam NVS menguji kemampuan pemahaman bacaan dan berhitung. Setiap jawaban yang benar mendapat skor satu. Jumlah skor kurang dari empat mengindikasikan tingkat literasi kesehatan yang rendah (Weiss et al,2005;Ozdemir, Alper, Uncu dan Bilgel,2009).

Hasil dari study pendahuluan yang dilakukan dapat dapat diketahui bahwa tingkat literasi kesehatan masyarakat di Puskesmas Banguntapan I masih tergolong rendah hal ini diketahui ketika peneliti melakukan uji coba terhadap 10 responden dengan menggunakan NVS (New Vital Sent) dari 6 pertanyaan mengenai sebuah label nutrisi es krim 7 dari 10 responden tersebut memiliki tingkat literasi rendah yaitu dengan skor 1-2 tergolong kategori rendah, peneliti menggunakan label nutrisi es krim karena untuk mengetahui tingkat literasi kesehatan masyarakat yang berobat di Pukesmas Banguntapan I dari hasil study pendahuluan masalah yang ada yaitu pengetahuan tentang literasi di Puskesmas Banguntapan I masih rendah. Maka dari itu peneliti ingin meneliti tentang faktor yang berpengaruh terhadap literasi kesehatan di Puskesmas Banguntapan I.

\section{METODE PENELITIAN \\ Rancangan penelitian}

Jenis penelitian yang digunakan pada penelitian ini adalah Deskriptif Kuantitatif dengan rancangan cross sectional. 
Populasi dan sampel

Populasi pada penelitian ini adalah masyarakat yang datang berobat ke Puskesmas Banguntapan I selama periode penelitian dengan jumlah populasi 31.900 selama 6 bulan terakhir pada bulan Maret - Agustus 2018. Pengambilan Sampel dalam penelitian ini adalah purposive sampling yaitu mengambil semua subjek yang berkunjung di Puskesmas Banguntapan I sampai jumlah sampel terpenuhi. Sampel yang digunakan dalam penelitian ini harus memenuhi kriteria berikut :

a. Kriteria Inklusi

1) Pasien tidak buta huruf

2) Pasien menyetujui untuk ikut serta dalam penelitian dalam menggunakan Informed Consent

3) Pasien tidak ada gangguan komunikasi

b. Kriteria Inklusi

1) Subjek tidak bersedia untuk mengikuti penelitian

2) Subyek menolak berpartisipasi dalam penelitian

\section{Analisis Data}

Analisa data pada penelitian ini adalah univariat dan bivariat. Analisis univariat menggunakan tabel, sedangkan analisis bivariat faktor yang berpengaruh terhadap literasi kesehatan masyarakat menggunakan uji Chi Square.

\section{HASIL}

\section{Univariat}

Berdasarkan hasil penelitian di Puskesmas Banguntapan I tahun 2018 yang dilakukan sejak Bulan Oktober sampai Bulan November 2018. Responden dalam penelitian ini sebanyak 100 responden. Responden dalam penelitian ini dapat dikategorikan dalam beberapa karakteristik yaitu usia, jenis kelamin, pendidikan dan pekerjaan Adapun hasil penelitiannya sebagai berikut :

\section{Analisis Univariat}

Analisis univariat dilakukan terhadap tiap variabel dari hasil penelitian dengan menggunakan distribusi frekuensi dan prosentase dari tiap variaabel serta dilengkapi dengan tabel (Soekidjo Notoadmojo, 2002). Data yang didapatkan dari kuesioner kemudian diolah menggunakan program SPSS 21.0 dan didapatkan hasil sebagai berikut:

a. Karakteristik Responden

1) Karakteristik responden berdasarkan Jenis Kelamin
Tabel 1

Distribusi Frekuensi Karakteristik

Responden Berdasarkan Jenis Kelamin di

Puskesmas Banguntapan I Bantul D.I.Y.

\begin{tabular}{c|c|c}
\hline $\begin{array}{c}\text { Karakteristik } \\
\text { Jenis Kelamin }\end{array}$ & Frekuensi & $\begin{array}{c}\text { Persentase } \\
(\boldsymbol{\%})\end{array}$ \\
\hline Laki-laki & 17 & $17,0 \%$ \\
\hline Perempuan & 83 & $83,0 \%$ \\
\hline Total & 100 & $100,0 \%$
\end{tabular}

Berdasaarkan tabel 1 dijelaskan bahwa hasil penelitian terhadap 100 responden, pada karakteristik responden berdasarkan Jenis Kelamin, masuk kategori laki-laki sebanyak 17 responden $(17,0 \%)$, dan Perempuan sebanyak 83 responden $(83,0 \%)$.

2) Karakteristik responden berdasarkan usia

Tabel 2

Distribusi Frekuensi Karakteristik

Responden Berdasarkan Usia di Puskesmas Banguntapan I Bantul D.I.Y.

\begin{tabular}{c|c|c}
\hline $\begin{array}{c}\text { Karakteristik } \\
\text { Usia }\end{array}$ & Frekuensi & $\begin{array}{c}\text { Persentase } \\
(\%)\end{array}$ \\
\hline $17-25$ & 19 & $19,0 \%$ \\
\hline $26-35$ & 24 & $24,0 \%$ \\
\hline $36-45$ & 31 & $31,0 \%$ \\
\hline $46-55$ & 18 & $18,0 \%$ \\
\hline$>55$ & 8 & $8,0 \%$ \\
\hline Total & 100 & $100,0 \%$ \\
\hline
\end{tabular}

Berdasaarkan tabel 2 dijelaskan bahwa hasil penelitian terhadap 100 responden, pada karakteristik responden berdasarkan usia, sebagian besar adalah masuk kategori 17-25 tahun yaitu sebanyak 19 responden $(19,0 \%)$, usia 26-35 tahun yaitu sebanyak 24 responden $(24,0 \%)$, usia 36-45 tahun yaitu sebanyak 31 responden (31,0 \%), usia 46-55 tahun yaitu sebanyak 18 responden $(18,0 \%)$, usia $>55$ tahun yaitu sebanyak 8 responden $(8,0 \%)$.

3) Karakteristik Responden Berdasarkan Pendidikan

Tabel 3

Distribusi Frekuensi Karakteristik RespondenBerdasarkan Pendidikan di Puskesmas Banguntapan I Bantul D.I.Y.

\begin{tabular}{c|c|c}
\hline $\begin{array}{c}\text { Karakteristik } \\
\text { Pendidikan }\end{array}$ & Frekuensi & $\begin{array}{c}\text { Prosentase } \\
(\mathbf{\%})\end{array}$ \\
\hline SD & 15 & $15,0 \%$ \\
\hline SMP & 17 & $17,0 \%$ \\
\hline SMA & 52 & $52,0 \%$ \\
\hline D3 & 6 & $6,0 \%$ \\
\hline S1 & 9 & $9,0 \%$ \\
\hline Pascasarjana & 1 & $1,0 \%$ \\
\hline
\end{tabular}


Total

Berdasarkan tabel 3 sebagian besar responden penelitian pendidikan terakhir,yaitu SD yaitu sebanyak 15 responden $(15,0 \%)$, SMP yaitu sebanyak 17 responden $(17,0 \%)$, SMA yaitu sebanyak 52 responden $(52,0 \%)$, D3 yaitu sebanyak 6 responden $(6,0 \%)$, S1 yaitu sebanyak 9 responden $(9,0 \%)$, Pascasarjana yaitu sebanyak 1 responden $(1,0 \%)$.

4) Karakteristik Responden Berdasarkan Pekerjaan

Tabel 4

Distribusi Frekuensi Karakteristik Responden Berdasarkan Pekerjaan di Puskesmas Banguntapan I Bantul D.I.Y.

\begin{tabular}{c|c|c}
\hline $\begin{array}{c}\text { Karakteristik } \\
\text { Pekerjaan }\end{array}$ & Frekuensi & $\begin{array}{c}\text { Prosentase } \\
(\%)\end{array}$ \\
\hline Tidak Bekerja & 55 & $55,0 \%$ \\
\hline Bekerja & 45 & $45,0 \%$ \\
\hline Total & 100 & $100,0 \%$ \\
\hline
\end{tabular}

Berdasarkan tabel 4 sebagian besar karakteristik responden penelitian di kategorikan berdasarkan pekerjaan yaitu responden yang memiliki pekerjaan dan tidak memiliki pekerjaan (ibu rumah tangga) responden yang tidak bekerja yaitu sebanyak 55 responden $(55,0 \%)$, dan responden yang bekerja yaitu sebanyak 45 responden $(45,0 \%)$.

5) Karakteristik Responden Berdasarkan Tingkat Literasi

Tabel 5

Distribusi Frekuensi Karakteristik

Responden Berdasarkan Tingkat Literasi kesehatan Masyarakat di Puskesmas Banguntapan I Bantul D.I.Y.

\begin{tabular}{c|c|c}
\hline $\begin{array}{c}\text { Karakteristik } \\
\text { Tingkat Literasi }\end{array}$ & Frekuensi & $\begin{array}{c}\text { Presentase } \\
(\boldsymbol{\%})\end{array}$ \\
\hline Rendah & 59 & $59,0 \%$ \\
\hline Sedang & 26 & $26,0 \%$ \\
\hline Tinggi & 15 & $15,0 \%$ \\
\hline Total & 100 & $100,0 \%$ \\
\hline \multicolumn{2}{c}{ Berdasarkan tabel 5 sebagian besar }
\end{tabular}
karakteristik responden memiliki tingkat literasi rendah 59 responden $(59,0 \%)$, sedang 26 responden $(26,0 \%)$, tinggi 15 responden $(15,0 \%)$.

\section{Analisis Bivariat}

Untuk mengetahui hubungan variabel bebas dengan variabel terikat digunakan uji Chi Square untuk mengetahui faktor- faktor yang berpengaruh terhadap tingkat literasi kesehatan.

Hasil analisis bivariat antara usia, pendidikan dan pekerjaan dengan tingkat literasi kesehatan masyarakat dapat di lihat pada tabel berikut ini.

Tabel 6

Pengaruh Usia Terhadap Tingkat Literasi

Kesehatan Masyarakat di Puskesmas Banguntapan I Bantul D.I.Y.

\begin{tabular}{|c|c|c|c|c|c|c|c|c|}
\hline \multirow[t]{3}{*}{ Usia } & \multicolumn{6}{|c|}{ Tingkat Literasi } & \multirow{2}{*}{\multicolumn{2}{|c|}{ Total }} \\
\hline & \multicolumn{2}{|c|}{ Rendah } & \multicolumn{2}{|c|}{ Sedang } & \multicolumn{2}{|c|}{ Tinggi } & & \\
\hline & $\mathrm{N}$ & $\%$ & $\mathrm{~N}$ & $\%$ & $\mathrm{~N}$ & $\%$ & $\mathrm{~N}$ & $\%$ \\
\hline $\begin{array}{l}17- \\
25\end{array}$ & 7 & $\begin{array}{l}36, \\
8\end{array}$ & 5 & $\begin{array}{l}26, \\
3\end{array}$ & 7 & $\begin{array}{l}36, \\
8\end{array}$ & 19 & $\begin{array}{l}19, \\
0\end{array}$ \\
\hline $\begin{array}{l}26- \\
35 \\
\end{array}$ & $\begin{array}{l}1 \\
3 \\
\end{array}$ & $\begin{array}{l}54, \\
2 \\
\end{array}$ & 7 & $\begin{array}{l}29, \\
2\end{array}$ & 4 & $\begin{array}{l}16, \\
7\end{array}$ & 24 & $\begin{array}{l}24, \\
0\end{array}$ \\
\hline $\begin{array}{l}36- \\
45\end{array}$ & $\begin{array}{l}1 \\
9\end{array}$ & $\begin{array}{l}61, \\
3\end{array}$ & $\begin{array}{l}1 \\
1\end{array}$ & $\begin{array}{l}35, \\
5\end{array}$ & 1 & 3,2 & 31 & $\begin{array}{l}31, \\
0\end{array}$ \\
\hline $\begin{array}{l}46- \\
55 \\
\end{array}$ & $\begin{array}{l}1 \\
3 \\
\end{array}$ & $\begin{array}{l}72, \\
2 \\
\end{array}$ & 3 & $\begin{array}{l}16, \\
7\end{array}$ & 2 & $\begin{array}{l}11, \\
1\end{array}$ & 18 & 18 \\
\hline$>55$ & 7 & $\begin{array}{l}87, \\
5\end{array}$ & 0 & 0,0 & 1 & $\begin{array}{l}12, \\
5\end{array}$ & 8 & 8,0 \\
\hline $\begin{array}{l}\text { Tota } \\
1\end{array}$ & $\begin{array}{l}5 \\
9\end{array}$ & 59 & $\begin{array}{l}2 \\
6\end{array}$ & 26 & $\begin{array}{l}1 \\
5\end{array}$ & 15 & $\begin{array}{l}10 \\
0\end{array}$ & 100 \\
\hline
\end{tabular}

Person Chi Square: 16,354

Sig 2-sided : 0,038

Berdasarkan tabel 6 dapat diketahui bahwa tingkat literasi kesehatan masyarakat di Puskesmas Banguntapan I berdasarkan usia tidak mempengaruhi tingkat literasi kesehatan. Hal ini ditunjukkan dengan nilai statistik hitung (Chi Square) sebesar 16,354 > dari statistic tabel (X2) sebesar 15,507. Nilai signifikasi $0,038<$ dari $=$ 0,05 menunjukkan bahwa usia mempengaruhi tingkat literasi kesehatan masyarakat.

Tabel 7

Pengaruh Pendidikan Terhadap Tingkat Literasi Kesehatan Masyarakat di Puskesmas Banguntapan I Bantul D.I.Y.

\begin{tabular}{c|c|c|c|c|c|c|c|c}
\hline \multirow{2}{*}{ Pend } & \multicolumn{6}{|c|}{ Tingkat literasi } & \multicolumn{2}{c}{ Total } \\
\cline { 2 - 9 } & \multicolumn{2}{|c|}{ Rendah } & \multicolumn{2}{|c|}{ Sedang } & \multicolumn{2}{c}{ Tinggi } & \multicolumn{2}{c}{} \\
\cline { 2 - 9 } & $\mathrm{n}$ & $\%$ & $\mathrm{n}$ & $\%$ & $\mathrm{n}$ & $\%$ & $\mathrm{n}$ & $\%$ \\
\hline SD & 15 & 100 & 0 & 0 & 0 & 0 & 15 & 15 \\
\hline SMP & 12 & 70,6 & 5 & 29,4 & 0 & 0 & 17 & 17 \\
\hline SMA & 32 & 61,5 & 19 & 36,5 & 1 & 1,9 & 52 & 52 \\
\hline D3 & 0 & 0,0 & 1 & 16,7 & 5 & 83,3 & 6 & 6 \\
\hline S1 & 0 & 0,0 & 1 & 11,1 & 8 & 88,9 & 9 & 9 \\
\hline S2 & 0 & 0,0 & 0 & 0,0 & 1 & 100 & 1 & 1 \\
\hline Total & 59 & 59 & 26 & 26 & 15 & 15 & 100 & 100 \\
& & & & & & & & \\
\hline
\end{tabular}

Person Chi Square: 88,563

Sig 2-sided : 0,000

Berdasarkan tabel 7 dapat diketahui bahwa tingkat literasi kesehatan masyarakat di Puskesmas Banguntapan I berdasarkan pendidikan mempengaruhi tingkat literasi kesehatan masyarakat. Hal ini ditunjukkan dengan nilai statistik hitung (Chi Square) sebesar $88,563>$ dari statistic tabel $(X 2)$ sebesar 18,307. 
Nilai signifikasi $0,000<$ dari $=0,05$ menunjukkan bahwa ada pengaruh antara pendidikan dengan literasi kesehatan masyarakat di Puskesmas Banguntapan I.

Tabel 8

Pengaruh Pekerjaan Terhadap Tingkat Literasi Kesehatan Masyarakat di Puskesmas Banguntapan I Bantul D.I.Y. 2018

\begin{tabular}{c|c|c|c|c|c|c|c|c}
\hline \multirow{2}{*}{$\begin{array}{c}\text { Pekerja } \\
\text { an }\end{array}$} & \multicolumn{6}{|c|}{ Tingkat literasi } & \multicolumn{2}{c}{ Total } \\
\cline { 2 - 8 } & \multicolumn{2}{|c|}{ Rendah } & \multicolumn{2}{c}{ Sedang } & \multicolumn{2}{c}{ Tinggi } & \multicolumn{2}{c}{} \\
\cline { 2 - 8 } & $\mathrm{N}$ & $\%$ & $\mathrm{~N}$ & $\%$ & $\mathrm{~N}$ & $\%$ & $\mathrm{~N}$ & $\%$ \\
\hline Tidak & 3 & 67, & 1 & 25, & 4 & 7,3 & 55 & 55 \\
Bekerja & 7 & 3 & 4 & 5 & & & & \\
\hline Bekerja & 2 & 48, & 1 & 26, & 1 & 24, & 45 & 45 \\
& 2 & 9 & 2 & 7 & 1 & 4 & & \\
\hline Total & 5 & 59 & 2 & 26 & 1 & 15 & 10 & 10 \\
& 9 & & 6 & & 5 & & 0 & 0 \\
\hline
\end{tabular}

Person Chi Square: 6,297

Sig 2-sided : 0,043

Berdasarkan tabel 8 dapat diketahui bahwa tingkat literasi kesehatan masyarakat di Puskesmas Banguntapan I berdasarkan pekerjaan mempengaruhi tingkat literasi kesehatan masyarakat. Hal ini ditunjukkan dengan nilai statistik hitung (Chi Square) sebesar 6,297 > dari statistic tabel $(X 2)$ sebesar 5,991. Nilai signifikasi $0,043<$ dari $=0,05$ menunjukkan bahwa ada berpengaruh antara pekerjaan dengan tingkat literasi kesehatan masyarakat di Puskesmas Banguntapan I.

\section{PEMBAHASAN}

a. Tingkat Literasi Kesehatan Berdasarkan Usia Hasil uji statistik dengan Chi Square menunjukkan adanya pengaruh antara usia dengan tingkat literasi kesehatan $(\mathrm{p}=0,038)$. Hasil penelitian ini menunjukkan usia berpengaruh terhadap literasi kesehatan. Hasil Penelitian yang dilakukan Ozdamir, Alper,Z., Uncu, Y.,\& Bilgel (2010) yang menunjukkan usia memiliki hubungan bermakna dengan literasi kesehatan. Walaupun secara statistik tidak bermakna, namun jika melihat distribusi tingkat literasi kesehatan diantara masing-masing kelompok usia $>56$ tahun proporsi tingkat literasi kesehatan yang tinggi adalah yang paling kecil $15 \%$ dibandingkan kelompok usia yang lebih muda.

b.Tingkat literasi kesehatan berdasarkan pendidikan

Hasil uji statistik menunjukkan nilai $\mathrm{p}=$ 0,000 yang berarti bahwa terdapat faktor yang berpengaruh antara tingkat pendidikan dengan literasi kesehatan. Pendidikan berperan dalam pembentukan pengetahuan serta keterampilan yang berhubungan dengan kesehatan. Pendidikan dapat mempengaruhi preferensi, perilaku serta gaya hidup seseorang yang pada akhirnya dapat mempengaruhi kesehatannya. Pendidikan juga meningkatkan kemampuan seseorang untuk mengumpulkan dan menginterpretasikan informasi kesehatan. Lebih lanjut lagi, pendidikan dapat membentuk kemampuan seseorang untuk selalu menambah atau memperbarui pengetahuan kesehatan yang telah dimilikinya melalui proses pembelajaran berkelanjutan (Canadian Council on Learning,2008). Tingkat literasi kesehatan yang dimiliki saat ini merupakan hasil dari proses pembelajaran individu sejak masa kecilnya, jenjang pendidikan sekolah dasar, sekolah menengah pertama, sekolah menengah atas, dan jenjang universitas menjadi kesempatan untuk meningkatkan literasi kesehatan. Pendidikan kesehatan harus dimulai sejak kanak-kanak dan terus bertambah secara berkelanjutan (Institute of Medicine, 2004).

c. Tingkat literasi kesehatan berdasarkan pekerjaan

Hasil uji statistik menunjukkan nilai $\mathrm{p}=$ 0,043 yang berarti bahwa terdapat faktor yang berpengaruh antara pekerjaan dengan literasi kesehatan. Pekerjaan berpengaruh terhadap literasi kesehatan dalam penelitian ini. Hasil ini berbeda dengan hasil penelitian JovicVranes dkk (2009) yang menyatakan bahwa literasi kesehatan yang tinggi lebih banyak ditemukan pada orang yang bekerja. Hasil dalam penelitian ini dapat disebabkan pengaruh variabel lain seperti pendidikan dan pendapatan. Misalnya, walaupun responden tidak bekerja, namun tingkat pendidikannya tergolong tinggi dan pendapatan keluarganya (dari anggota keluarga lain yang bekerja) mencukupi.

\section{SIMPULAN}

Berdasarkan hasil penelitian di puskesmas banguntapan maka dapat disimpulkan :

1. Ada pengaruh Usia terhadap literasi kesehatan hal ini berarti semakin bertambah usianya semakin tinggi literasinya.

2. Ada pengaruh pendidikan terhadap tingkat literasi kesehatan, dimana semakin tinggi tingkat pendidikan semakin tinggi literasinya.

3. Ada pengaruh antara pekerjaan dengan tingkat literasi kesehatan hal ini berarti literasi kesehatan yang tinggi ditemukan pada orang orang yang bekerja. 
Volume 02, No 01, Tahun 2019

ISSN: 2621-6612

Email: d3perinfokesunivet@gmail.com

Halaman: 26-31

\section{DAFTAR PUSTAKA}

Canadian Council on Learning. (2008). Health Literacy in Canada:a Healthy Understanding. Maret 20, 2012. Canadian Council on Learning. http://www.cclcca.ca

Jovic-Vranes, A., Bjegovic-Mikanovic, V., Marinkovic, J. (2009). Functional health literacy among primary health-care patients: data from the Belgrade pilot study. Journal of Public Health, 31(4),490-495

Nazmi, Rudolfo, Restila.(2015). Faktor-faktor yang mempengaruhi literasi kesehatan di fasilitas pelayanan kesehatan.

Nurjanah., Sri Soenaryati., Enny Rachmani. Health Literacy pada Mahasiswa Kesehatan, Sebuah Indikator Kompetensi Kesehatan yang Penting. Universitas Dian Nuswantoro Semarang. 2015

Nurjanah N, Rachmani E, Manglapy YM. Assessing Health Literacy on Student using Online HLS-EU-16. In: International Seminar on Public Health and Education. Semarang: Postgraduate Program Semarang State University; 2015.p. 238-243.

Ozdemir, H., Alper, Z., Uncu, Y., \& Bilgel, N. Health Literacy Among Adults : A Study From Turkey. Health Education Research, 25(3), 464-477. 2010

Pawlak, R. (2005). Economic Considerations of Health Literacy. 2005. Nurs.Econ, 23(4), 173-180.com

Principles KL, Posts R. The Newest Vital Sign. Lancet Neurol. 2011;10(5):411.

Purwanti Hadisiwi , Jenny Ratna Suminar. Literasi Kesehatan Masyarakat Dalam Menopang Pembangunan Kesehatan Di Indonesia.

Santosa, Karina Samaria. Faktor - Faktor yang Berhubungan dengan Tingkat Kemelekan Kesehatan Pasien Klinik Dokter Keluarga Fakultas Kedokteran Universitas Indonesia Kiara. Universitas Indonesia. Jakarta. 2012

Soronsen, K., S Van den Broucke, J Fullam, 2012. Health Literacy and Public Health : a Systematic Review and Integration of Definition and Models.BMC Public Health

Sugiyono, Metode Penelitian Pendidikan. Bandung: Alfabeta,2010
Weis, B.D. MZ Mays, W Martz. (2005). Quick Assessment of Literacy in Primary care: The Newest Vital Sign. Annals of Family. Medicine, 3(6), 514-522

White, S. (2008). Assessing the Nation's Health Literacy. American Medical Associtation Foundation, Amerika Serikat.

World Health Organization. (1998). Health Promotion Glossary. Geneva:Division of Health Promotion, Education and Communication. 